\title{
Concha Győző és a rendőri erények
}

\section{NÁNDORI Nikoletta Petra ${ }^{1 \oplus}$}

\begin{abstract}
Miért fontosak a rendörök számára az erények? A rendőri hivatás feladatellátásához olyan képességek szükségesek, amelyekkel a mindennapi szolgálat a lehető legjobban végrehajtható. Ezeket a magyar közjogtudomány egyik jeles képviselője, Concha Győző munkásságán keresztül vizsgálom kiemelten, mellette azonban szerepet kap a témához kapcsolódóan további írók munkássága is. A tanulmányban olyan erényeket keresek, amelyeknek helye volt a rendőrség munkájában a dualizmus korában. Az állami és társadalmi berendezkedéstöl független olyan elemek felkutatása a célom, amelyek a rendôr végrehajtói munkáját lehetóvé téve ma is meghatározó jelentőségüek.
\end{abstract}

Kulcsszavak: rendőri erények, állandó őrködés, diszkrecionális hatalom, fizikai erő alkalmazása

\section{Bevezetés}

A rendőri erényeket az alábbi tanulmányban kiemelten Concha Győző munkássága alapján szűröm ki. A vizsgálat szempontjából a központi szerepet a következő két írása fogja képviselni: A rendốrség természete és állása a szabad államban címmel írt székfoglaló értekezése és a Politika I. Alkotmánytan címmel megjelent kötete. Mindkét mủ a dualizmus korában jelent meg, amikor a belügyi viszony megerősítése különösen nagy jelentőségú volt. Az Osztrák-Magyar Monarchia korában az állami berendezkedést a dualista politikai rendszer határozta meg. Az alkotmányos monarchia évtizedeiben azonban Magyarország belső ügyeivel összefüggésben teljes mértékben önálló maradt. A rendészeti tevékenységet a Magyar Királyi Belügyminisztérium irányította.

Ebben az állami berendezkedésben a 19. és a 20. század elején fejtette ki mélyreható gondolatait tudományos tevékenységével Concha Győző jogtudós. ${ }^{2}$ A rendőrség és annak müködése a kor közigazgatási rendszerének szerves részét képezte, amelyre kellő rálátást nyújtanak Concha Győző munkái.

\footnotetext{
Nándori Nikoletta Petra r. főhadnagy, Nemzeti Közszolgálati Egyetem Rendészettudományi Doktori Iskola, doktori hallgató.

Nikoletta Petra Nándori, Police First Lieutenant University of Public Service, Doctoral School of Law Enforcement, PhD student. E-mail: nandori.nikoletta.petra@uni-nke.hu

2 Sallai János: Concha Győző, a rendészet jeles tudósa. Magyar Rendészet, 15. (2015), 1. 39.
} 


\section{Az állam kialakulásától a végrehajtó hatalomig}

A rendőri erényekről a tanulmány második felétől kezdődően fogok írni. Azt megelőzően a rendőri hivatás társadalomban betöltött szerepét fejtem ki. Kezdve az állam kialakulásától, egészen a végrehajtó hatalom funkciójáig. A tanulmány célja, hogy Concha Győző általam vizsgált művei nyomán olyan erények feltárására vállalkozzam, amelyeket a rendőri múködés (feladatkör, társadalmi szerepkör) meghatározó elemeiként határozott meg.

\section{Az állam kialakulása}

Az állam vagyis nemzet kialakulását Concha Győző (1846-1933) a Politika I. címú könyvében az ember világáról, az abban kialakuló emberi életről és annak felépítéséről írta. Eszerint az ember önmeghatározó erejét az ember eszméje felől közelíti meg, amelyet véleménye szerint a szellemiség, egyetemesség és a szabadság határoz meg. ${ }^{3} \mathrm{Az}$ emberi eszme az egyén és köz viszonya alapján, a maga erejéből hozza létre a köztudatot, és teszi lehetővé ezáltal a szellemnek egyetemes érvényre jutását. A közösség működésének Concha szerint, emberileg csak akkor lesz értéke, ha a köz tagjai akaratuktól támogatott öntudattal rendelkeznek, vagyis csak az emberek közösségében megvalósuló egyéni érvényesülés által, a maga teljességében nyer megerősítést. ${ }^{4}$ A közön Concha a törzset, a társadalmat, a családot, de magát az államot is értette. ${ }^{5}$

\section{Az emberi eszme szerepe}

A szellem Georg Wilhelm Friedrich Hegel meghatározása szerint lényeges szerepet játszik az ember létezésében, hiszen azzal együtt emelkedik az ember univerzálissá. Kiteljesedni pedig igazán a társadalomban képes. ${ }^{6}$ A tárgy és a dolog együttese, vagyis az én és a lét egysége alkotja az öntudatot. ${ }^{7}$ Az öntudat, más néven szellem, erkölcsi szubsztancia, vagyis maga az emberi tudatosság. ${ }^{8}$

„Hegel szerint igaz ez az államra nézve is, mivel az is rendelkezik erkölcsi személyiséggel. Az állam ugyanis több a tagjai összeségénél, mivel jelentősége van annak, hogy az államban a tagokat nem csupán az erőszak kapcsolja össze, hanem bizonyos erkölcsi értékek (is). Az állam így egység, a tagjai erkölcsi közössége, azaz a jó élet vezetését meghatározó

\footnotetext{
Concha Győző: Politika I. kötet Alkotmánytan. Budapest, Eggenberger-féle Könyvkereskedés (Hoffmann és Molnár), 1895. 33

Concha (1895): i. m. 35.

Concha (1895): i. m. 34.

Charles Taylor: Hegel. Cambridge University Press, 1975. 366.

Georg Wilhelm Friedrich Hegel: A szellem fenomenológiája. Budapest, Akadémiai, 1979. 180.

Hegel (1979): i. m. 180-182.
} 
erkölcsi értékek (Hegel kifejezésével: szellem) mentén megszerveződő emberi közösség. Ezzel összefüggésben az állam tagjai azáltal lesznek azok, akik, hogy tagjai egy náluknál nagyobb, ezért felsőbbrendúbb egységnek, amiért hajlandók feláldozni az egyéni érdekeiket."

Az emberi eszme irányait tekintve kiemelten a vallásban, a múvészetben és a tudományban valósulhat meg a közösségben, amelyen túlmenően még a gazdálkodásban, fajfenntartásban és nevelésben is összpontosul. Az emberi eszme belső ereje, az erkölcsi érzülettel átitatott erkölcsi magatartás eredményeképpen valósulhat meg és kerülhet általa összhangba. Az emberi cselekvés külső szabályozásáért a jog felelős. ${ }^{10}$

\section{Az emberi eszme és az állam lényegérôl}

Az egyéntől a nemzetbe történő átmenetet a család fogja képviselni. A családi közösségben a tagok a természetes és szellemi szeretet által tudnak egyenlően érvényesülni. ${ }^{11} \mathrm{Az}$ állam társadalomból és családból való kiválásával, az ember egyetemes eszméje, az egyén önállóságával együtt öntudatossá válik. A köz országló (értsd alatta: kormányzó, kormányon lévő) külső erejének, irányzó funkciójának köszönhetően, az egyénektől függetlenné válik, és így hozza létre az emberek között azt az erőt, amellyel az egyéni érdekeket külső hatalom nélkül is mérsékelni képes. Az állam így válik ki tehát a társadalomból, és jut általa állandó érvényre az ember egyetemes eszméje. ${ }^{12}$ „Az egyetemes jó tudatát, az ember eszméjét a jól felfogott érdek és az egyénekben működő felebaráti szeretet készíti elő."13 A nemzet mint az egyének erkölcsi és értelmi valójának egésze alkotja a vagyonilag és szellemileg müködő egyéneket. ${ }^{14}$

$\mathrm{Az}$ állam mint a külső rend és külső szabadság irányzója van jelen a tulajdon, a szerződések, a rendőri tilalmak és a büntető törvény határozmányai (értsd alatta: előírás, rendelkezés, paragrafus) által.

Concha szerint az állam személyisége révén valósulhat meg az általános jó. Az államban ez a jó, vagyis az ember eszméje annak mint öntudatos akaratnak tartalmaként lép fel. A külső alakzat, a lény, amelyhez az államtevékenység kötve van, bizonyos földterületen élő, gazdasági, társadalmi vagy faji kötelékeinél fogva alkot természetes egészet, a népet. ${ }^{15}$

$\mathrm{Az}$ állam emberi ábrázolását Thomas Hobbes Leviatánnak nevezte, ami az ugyanezen címet viselő 1651-ben megjelent művének címlapján megtalálható. A Leviatán

\footnotetext{
Boda Mihály: A filozófiára épülő háborús igazolás (filozófiai militarizmus) a 19-20. században Európában és Magyarországon. Hadtudomány, (2021), (megjelenés alatt).

10 Concha (1895): i. m. 41.

Concha (1895): i. m. 185.

Concha (1895): i. m. 188.

Concha (1895): i. m. 189.

Concha (1895): i. m. 189.

Vö. Concha (1895): i. m. 198.
} 
maga is több emberből tevődik össze, utalva ezzel arra a felismerésre, amelynek eredményeképpen az emberek értelmi úton ismerik fel - de a természeti állapot következményeitől való félelem miatt fogadják el -, hogy a békés együttélés alaptörvényeinek betartásához kényszerítő eszközre - vagyis államhatalomra van szükség. ${ }^{16}$

$\mathrm{Az}$ államban az ember eszméje, az általános jónak nemzeti alakja érvényesül, amelyben az egyesek öntudatának az öntudattal rendelkező érzése az akaratának részévé válik. A nemzeti öntudat, vagy más néven hazafiság, tehát az intézmények iránt kifejezett szeretet, hazaszeretet, amelyekben az általános jó nemzeti alakban jelenik meg, vagy törekvés az ilyen intézmények megteremtésére, fenntartására az egyén erőinek igénybevételével és áldozatkészségével. ${ }^{17}$

$\mathrm{Az}$ államban az ember eszméje a nemzeti alak általános jóságával képes érvényre jutni, a társadalom tagjainak öntudatával. A nemzet tagjának öntudata, szeretete által válik tehát öntudatos alkotássá, vagyis hazafivá. A nemzeti öntudatot, vagyis a hazafiságot a hazaszeretet jellemzi. Az általános jó, amely ebben a tekintetben a nemzet alakjában jelenik meg, és az egyén e nemzet érdekében áldozatkészséggel törekszik az általános jó elérésére. ${ }^{18}$

\section{A szuverén és végrehajtói akarat}

A szuverén akarat, vagyis az állam akarata akkor teljes, ha mindhárom akarat egyszerre érvényesül, ezek a belső elhatározás, a külső cselekvés és végelhatározás. ${ }^{19}$

$\mathrm{Az}$ államhatalmak közül a belső akarat határai között mozgó végrehajtó akarat, a törvény megvalósulását lehetségessé tevő, annak előfeltételeit, pénzt, helyiségeket, hivatalnokokat, általános utasításokat előteremtő működése a jogosság szempontjából: ekkor bíráskodó vagy külső erő szempontjából a karhatalom biztosítja. ${ }^{20}$

\section{A végrehajtói tevékenység}

Az állam cselekvő, végrehajtó tevékenysége, az állami szuverén akarattól elkülönült, önerővel működő egységes jelensége tehát. Az állami akarat megvalósulása ugyanis csak karhatalom alkalmazása útján lehetséges. Amit olyan szervezetként aposztrofál Concha, amely az államnak az erkölcsi és gazdasági, vagyis közpolgári céljaitól való eltérést nem engedi. ${ }^{21}$

\footnotetext{
Thomas Hobbes: Leviatán. Budapest, Kossuth, 1999. 210.

Concha (1895): i. m. 236-237.

Boda Mihály: Zrínyi hősiességfogalma a katonai hősiesség változó formáinak tükrében. Hadtudományi Szemle, 13. (2020), 2. 84-85.

Concha (1895): i. m. 272.

Concha (1895): i. m. 276.

Vö. Concha (1895): i. m. 494.
} 
A jó állam kiemelt feladata az általános emberi akarat képviselete. A végrehajtás a kormány feladata, ami a főhatalom és a társadalom közé iktatott testület. A törvényhozás a társadalomra tartozik, ezért közvetlenül vesznek részt a döntéshozatalban, ennélfogva az nem a közhivatalnokok vagy a főhatalom képviselőinek a feladata. A törvény tehát az általános emberi akarat megnyilvánulása. A törvények célkitűzései elsősorban a szabadság, valamint az egyenlőség. ${ }^{22}$ „Az általános akarat az a társadalomra jellemző, és a társadalom tagjaiban testet öltő akarat, amely csak a közérdeket (és az igazságosságot) tartja szem előtt, és egyetlen egésszé, egyetlen közösséggé egyesíti a társadalom tagjait." ${ }^{23}$

A társadalmi szerep ebben az értelemben tehát a rendőri hivatás, amely a hivatásos szolgálatot, vagyis a közjó szolgálatát jelentette. A rendőrség az állam létének szükséges eleme, mivel az állam karhatalom nélkül nem létezik. A társadalom és a rendészeti állomány közötti optimális kapcsolat kialakítása visszahat a köz biztonságérzetére és a társadalmi rend fenntartásának lehetővé tételére, amelynek következtében az államérdek megvalósulhat. E témakörnek bővebb kifejtésére a következő részben kerül majd sor.

\section{A rendőrség társadalmi szerepvállalása Concha Győző nyomán}

$\mathrm{Az}$ állami és társadalmi jelenségek között nincs még egy, amelynek természetét illetően annyira eltérne a felfogás a tudományban és az életben, mint a rendőrség müködését illetően, fejti ki Concha Győző A rendőrség természete és állása szabad államban címet viselő székfoglaló értekezésében. Mindemellett különbség mutatkozik a rendőrség állása (működése), az emberi életben betöltött szerepe/szolgálata és a rendőri hivatás értékének megállapítása között is. Az állami és társadalmi szervezet és a rendőri működés kapcsolatát az ember nélkülözhetetlen java felől közelíti meg, ami a szabadságnak sorsa. ${ }^{24}$ A rendőrség természetének kutatását a rend fogalmának meghatározásával kezdi, amelyet a közrend követ.

\section{A közrendröl és annak elemeiröl}

A közrendet az állam és a társadalom rendje közösen alkotja. A rend alatt több külön dolognak, lénynek, erőnek olyan összefüggését érti, amely szerint ebben az összefüggésben lévők helyüket, müködésüket az egészre tekintet nélkül meg nem változtathatja. Ha pedig mégis megváltozik, akkor az összefüggés megszakad, és a cél, amely miatt az egyes elemek ilyen összefüggésbe kerültek, elérhetetlen lesz. A közrend

\footnotetext{
22 Vö. Jean-Jacques Rousseau: A társadalmi szerződésrôl. Budapest, PannonKlett, 1997. 30-40.

23 Boda (2020): i. m. 84.

24 Concha Győző: A rendőrség természete és állása szabad államban. Értekezések a Társadalmi Tudományok Köréből, 12. (1901), 6. 299.
} 
egyik oldalról az emberi tevékenységnek, vagyis a munkának; másrészt a különböző javaknak (vagyon, múveltség, erkölcs, becsület, hatalom) megosztása és összefüggése személyek, helyek és idő szerint. Ilyen értelemben tehát a közrendet a nemzeti és az egyéni társadalmi lét összmúködésének, különböző javaknak a megosztása, majd pedig az általuk való élvezése alkotja. A közrend, a béke állapota, a rend minden embernek közös célja, ami az emberek egyéni szükségleteiben és az állami múködés egyensúlyában létezik. Az állam és a társadalom rendje közösen alkotják tehát a közrendet, amelyhez tágabb értelemben a természet rendjét is értette. ${ }^{25}$

\section{Az állami rend}

$\mathrm{Az}$ állam rendjét Concha Győző szerint a fejedelem, az országgyúlés, a kormány, a bírói és közigazgatási hatóságok munkájának a társadalom által elfogadott szabályok szerinti összefüggése alkotja. Az állami rend egyik alkotóelemeként határozza meg magát a rendőri múködést, amelynek a jog szabályainak érvényre juttatása mellett feladata az állam rendjének létrehozása és fenntartása. Az állam érdeke pozitív alkotóelemeként a jog által, a belügyekben a közgazdaságot, a közerkölcsöt és a közegészséget illetően kíván célt elérni. Az állam rendje Concha szerint akkor bomlik meg, ha az állam szervei nem végzik jól a munkájukat, nem tartják meg munkájuk mértékét, körét és egymásutánját. ${ }^{26}$

\section{A társadalmi rend}

$\mathrm{Az}$ egyénből kiindulva a munkavégzésnek, gazdasági, szellemi javaknak és ezek alapján képződő egyéni érdekeknek biztos eloszlása képezi. A jog és jogszolgáltatás önmagában nem tekinthető rendőri tevékenységnek, ahogy ilyen értelemben a másik végletként megnyilvánuló társadalmi meggyőződés, vagyis a jog hasznosságán felülemelkedő hit szentsége sem. ${ }^{27}$

A társadalmi rend múködési szabadságát a jog érvényesülése által látta Concha biztosítottnak. Azonban a jogon és jogszolgáltatáson túl a társadalmi rend alkotóelemeit véleménye szerint az egyesek szabad együttmúködése; a javak helyes megoszlása; felebaráti érzés és az egyesek hite, meggyőződése tartják fenn. ${ }^{28}$

\footnotetext{
Vö. Concha (1901): i. m. 299-301.

Concha (1901): i. m. 301-302.

Concha (1901): i. m. 302-303.

Concha (1901): i. m. 305.
} 


\section{A természet, az elemek rendje}

A természeti világ rendje a természeti erőknek, elemeinek ismétlődő egymás után bekövetkező és egyúttal ismétlődő és egymásra ható eseményeinek kapcsolatán alapul. A természet rendjének megbomlása (járványok, természeti katasztrófák) kihatással van az állam és társadalom megbomlására is. A természet rendjének fenntartója nem a természeten kívül álló rendőrség, hanem a természet maga. ${ }^{29}$ A természet önfenntartó voltáról Hegel is ír, aminek értelmében természetes létező ok-okozati összefüggésben létező természetfogalomként aposztrofálja. ${ }^{30}$

\section{A rendörség múködéséröl}

$\mathrm{Az}$ állam és a társadalom rendjének fennállása attól függ, hogy a nekik szánt múködés kifejtését, javak megoszlását, azoknak a használatát zavartalanul, a jog szabályai és az államérdek követelményei szerint lehessen érvényesíteni. A rendőrség feladatai az alaptényezők mellett az állam és a társadalom rendje előfeltételeinek biztosítása, a társadalmi rendnek az érvényesülését lehetővé tenni és nem magát a rendet. ${ }^{31}$

$\mathrm{Az}$ állami rend elöfeltétele, hogy az államfö, a parlament és a hatóságok múködhessenek. A rendőrség feladata az állami rendet illetően pedig épp abban áll, hogy azok zavartalanul müködhessenek, és ténylegesen, akár külső erővel is lehetővé tegye azt az egyén vagy rossz szándékú tömeg és a természeti erők hatalmával szemben is. ${ }^{32}$

\section{A rendôrség a társadalmi rend elôfeltételeinek biztositását a következöképp hozza létre}

A rendőrség elsősorban úgy hozza létre a társadalmi rend feltételeit, ha az egyesek a jog által engedélyezett szabad múködését és javait állandó őrködésével védelmezi a valószínűsíthető és a ténylegesen bekövetkező támadás ellen; az így felmerülő támadásokat tényleg megakadályozza; a támadásokkal megzavart rendet pedig helyreállítja. Másodsorban az által állítja elő a társadalmi rend feltételeit, amenynyiben az egyesek szabad müködését - ha abban jogsérelem nincs - megakadályozza, őket valaminek a tevésére szólítja fel. Tekintettel arra, hogyha azok szabad múködése (tevékenysége) mások megsértésére, szabadságuk korlátozására, vagyis a múködésükben valamilyen formában zavart okozhat. A rendőri megakadályozás, vagyis a rendőri kényszerítés valaminek a létesítésére azonban csak ideiglenes

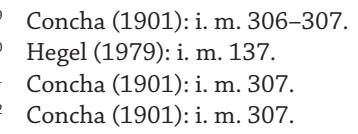


állapotot idézhet elő. Az így kiszabott bủntettnek pedig arányosnak kell lennie a büntetéssel. Harmadszor pedig az elemi, tehát a természeti erôk rendkívüli kitörésének megfékezésében keresendők a társadalmi rend előfeltételei. Ezek a természeti katasztrófák a társadalom mindennapi rendes kerékvágás szerinti életének rendjét megakaszthatják. ${ }^{33}$

A közrend tágabb értelemben azt jelenti, hogy az emberi szükségletek az állami szervek és egyének (társadalom tagjai) együttes és összehangolt múködésével, az általános és közös jó figyelembevétele mellett, a jog és a természeti erők korlátai között kell, hogy érvényesüljenek. ${ }^{34}$

A jog és természeti erők korlátai között, a rendőri müködés a közhatalom azon tevékenysége, amely összehangolt múködése és a szükségletek - emberi akarattól vagy természeti erőtől függő - előfeltételeinek a kielégítését állandó őrködéssel, széles körű diszkrecionális (mérlegelési) hatalommal és fizikai erőnek azonnali alkalmazásával tartja fenn. ${ }^{35}$

\section{A rendôri müködés természetéröl}

A rendőri működés természetének megállapítása érdekében mindenesetre az első követelmény a kielégítendő szükséglettel összefüggésben Concha Győző szerint az, hogy a kielégítése módját és annak alanyát egymástól elkülönítve kezeljék. A szükségletet a közrendet az emberi szabadságtól és természeti erőktől függő előfeltételekkel kell véleménye szerint ellátni. A rendőri múködés a szükségletkielégítő funkciója szempontjából abban különbözik tehát elsősorban más állami múködéstől, hogy ezek magát az állam célját, illetôleg annak egyes részeit, úgymint a nemzeti függetlenséget, a jogot, a közvagyonosodást, műveltséget, erkölcsöt ápolják. Addig a rendőrség csak mindezeknek az előfeltételeit biztosítja, vagyis azt a külső és időleges biztonságot, amely a tulajdonképpeni célok érdekében, szükségszerủen kifejtett tevékenységével, annak a pozitív érvényre juttatását és zavartalan múködését teszi lehetővé. A rendőrség ezeknek csak segédje, müködésüknek részben pozitív feltételeirôl gondoskodik, másrészről pedig az akadályokat hárítja el az útból. Másodszor pedig abban különbözik a rendőrség által kielégített szükséglet más állami szükséglettől, hogy folyamatos gondozást és őrködést igényel. Az emberek percről percre történő megfigyelését és a legegyénibb alakulataiba történő rögtöni, karhatalmi beavatkozást kíván meg az illetékes hatóság alanyi belátása, diszkrecionális hatalma alapján. Alkalmazkodás a természeti világ változó körülményeihez. ${ }^{36}$

\footnotetext{
Vö. Concha (1901): i. m. 307-308.

Concha (1901): i. m. 301.

Concha (1901): i. m. 309.

Concha (1901): i. m. 311.
} 
„Az állandó őrködés és a diszkrecionális hatalom teszik a rendőri múködésnek legsajátosabb eszközeit." ${ }^{37}$

A rendőrség múködésének határát maga a jogrend képezi, amelyet a rendőrség át nem léphet és ezáltal e jogrend által meghatározott körön láthatja el feladatát. Ilyen tekintetben, a jogrendben a rendőrség jogrendje egy különös, a közrend előfeltételeinek meghatározására vonatkozó, alárendelt jogvidék. ${ }^{38}$

\section{A rendôri múködés különleges eszközei}

A rendőri múködés elemei a következők Concha Győző szerint: a) az emberi élet, állami úgy, mint társadalmi élet folyásának, e folyamat minden mozzanatának szakadatlan szemmel tartása, kivéve az egyén magán szentélyében (család, ház, levél) környezetében zajlódó eseményeket; b) az alanyi belátás, a discretionarius hatalom minden rendőri közegnél vagy legalábbis minden rendőri hatóságnál annak megtételére, amit a közrend előfeltételnek tart. ${ }^{39} \mathrm{~A}$ rendôri múködés (feladatellátás) legsajátosabb eszközei tehát az állandó őrködés és a diszkrecionális hatalom. A rendőrség múködésének határát a jogrend maga képezte, de adódhat olyan különleges állapot, amikor is a jog fölé helyezkedik, ezt magas vagy politikai rendőrségnek nevezi. Erről a következőkben lehet olvasni.

\section{A magas vagy politikai rendörség}

A diszkrecionális hatalom különösen a politikai rendőrségben van jelen. A magas vagy politikai rendőrség a feladatát tekintve az állam vagy a társadalom biztonságával foglalkozik, méghozzá azokkal, amelyek tömegjelenségek ellen irányultak. A politikai rendőrség gyakorlatilag a rendőri múködésnek legfontosabb ága, amely az alkotmány egészére kihatással van és rendelkezik egyúttal a legmagasabb fokú diszkrecionális hatalommal. A magas rendőri müködésnek a diszkrecionális hatalmában a jogrend nem képez már határt. ${ }^{40}$

A magas vagy politikai rendőrség a törvényhozó hatalom felé nyújt biztositékot: a szabályokat is csak annyiban, amennyiben a kivételes állapotok létesítésére vagy más magas rendőri intézkedésre okot szolgáltató körülményeket általában meghatározza, a rendőrség eszközeit, eljárási módjait, beavatkozási határait általában körülírja; a szabályai általánosak, mindenkire kiterjedók és nem részrehajlók, tehát nem az egyesek vagy osztályok ellen irányulók; a politikai a rendőrség legerősebb, legdiszkrecionáli-

\footnotetext{
Concha (1901): i. m. 328.

Concha (1901): i. m. 322.

Vö. Concha (1901): i. m. 327-328.

40 Vö. Concha (1901): i. m. 333-334.
} 
sabb eszköze, a kivételes állapot létesítése élesen elhatárolódik a rendes állapottól, kezdetének és megszűnésének különös megjelölése, kihirdetése által. ${ }^{41}$

\section{Az erényekröl általában}

Az erényekről szóló részre a tanulmány szempontjából azért van szükség, mert ennek segítségével olyan szemléletmód átvezetésére nyílik lehetőség, amivel az eddig feldolgozott szakirodalmak még átláthatóbbá, és a kutatás szempontjából feltárt erények várhatóan megismerhetőbbé válhatnak általa.

Mielőtt belevágnék az erények bővebb kifejtésébe, azelőtt a fogalmának meghatározásával kezdem. Az erény egyfajta viselkedési mód és érzés, egyfajta törekvés, készség, ami iránymutatásul szolgál arra, hogy adott helyzetekben bizonyos módon cselekedjünk. $^{42}$

Arisztotelész Nikomakhoszi etikája szerint az erényeket a következőképpen lehet osztályozni: észbeli és erkölcsi erények. Az észbeli erények: a bölcsesség, az éleslátás és az okosság; az erkölcsiek: a nemes lelkű adakozás és a mértékletesség. Ennélfogva, ha tehát az erkölcsről beszélünk, akkor nem azt mondjuk, hogy az illető bölcs vagy éles eszű, hanem mindinkább azt, hogy szelíd vagy mértékletes. ${ }^{43}$

$\mathrm{Az}$ államtudomány végcélja szerint magában foglalja a többi tudomány céljait is, amely szerint ez a cél az ember számára való jó. ${ }^{44}$ A legfőbb jónak a cselekvéssel elérhető jót tekinti, aminek tökéletesnek kell lennie. Az államkormányzás végcélját tekinti Arisztotelész a legjobbnak, márpedig az államkormányzásnak a legnagyobb gondot arra kell fordítania, hogy a polgárait valamilyenekké, éspedig jókká tegye. Alkalmassá és képessé tegye őket arra, hogy erkölcsi jót cselekedjenek. ${ }^{45}$

$\mathrm{Az}$ erény a magatartásban, vagyis a tettekben megmutatkozó olyan emberi jó cselevés, amely ugyan tudatában van a cselekedetének lehetséges rossz mivoltával, azonban a végső cselekvését nem az határozza meg, hanem mindinkább a jó és a jóra való törekvése. Az emberek erkölcsi szempontból ideálisan elvárt viselkedésével Arisztotelész szerint valamilyen erkölcsi szempontból fontos cél elérése a végcél, amely tevékenység alapvetően a közösség feladata. ${ }^{46} \mathrm{Az}$ erények olyan jó cselekedetek, amelyek által a személyiségjegyek egyedivé válhatnak. Az egyedi volta által válik meghatározhatóvá az, hogy az egyes hivatásrendeken belül milyen erények azok, amelyekkel a hivatás gyakorlása jobbá tehető. A jó személyiségjegyekkel rendelkező ember jó cselekedeteket fog végrehajtani, ahogy a jó tettek mögött is jó szándék lapul. A jó cselekedetek tanulhatók, a normákat meghatározó tulajdonságok

\footnotetext{
Sallai (2015): i. m. 42.

Nigel Warburton: Bevezetés a filozófiába. Budapest, Kossuth, 2000. 65.

Arisztotelész: Nikomakhoszi Etika. (Részletek, I-III. könyv). (Fordította: Szabó Miklós). Budapest, Európa, 1997. 12.

44 Arisztotelész (1997): i. m. 1.

5 Arisztotelész (1997): i. m. 8.

46 Boda Mihály: Az alapvető katonai erények mibenléte és helyük a hosszú 19. századi magyar hadtudományos gondolkodásban 1. rész - Az erények és a katonai erénylisták. Hadtudomány, 28. (2018a), 1. 38.
} 
elsajátíttatása a közösség feladata. A jó tulajdonságok erősítése és a jóra nevelés egyre természetesebbé válik, végül belsővé. A rendőri hivatás közössége a rendőri szervezet maga. A jó emberből jó rendőr lesz, aki hivatását a jó szellemében fogja gyakorolni. Az erények és a személyiség jegyei elő fogják segíteni a jó cselekedetet.

Az erénnyel elérhető cél a belső jó elérése, amely az együttműködésen alapuló tevékenységgel valósítható meg Alasdair MacIntyre szerint. A belső jók az újra és újra megtett próbálkozásokból fakadnak, tehát gyakorlással, fejlődés útján sajátíthatók el. ${ }^{47}$

$\mathrm{Az}$ erényeket befolyásoló tényezők az úgynevezett hajlamok, azok a helyes viselkedésre sarkalló tényezők, amelyek szokássá tehetők. A szokások pedig reflexekké, amelyek az emberi viselkedést egy adott cselekvésben, a belsőből induló jó reakciót természetességgel váltják ki.

$\mathrm{Az}$ erények ideális hajlamok, és a hozzájuk kapcsolódó helyes viselkedéssel szemben többféle erkölcsi és morális szempontból elvárásként támasztott kötelesség vagy parancs fogalmazható meg. Attól függően, hogy az erkölcsi normák milyen közösség számára fogalmaznak meg kívánalmakat, erények szempontjából ideális hajlamokat, válik egyúttal a tanulmány szempontjából a rendőri hivatásban szolgálatot teljesítő rendőrök számára meghatározóvá.

\section{A rendörök számára fontos erények, amelyek a szakirodalmakból kiolvashatók}

A rendőri erények alatt ebben a részben olyan, a rendőri működést meghatározó különleges eszközöket értek, amelyek Concha Győző szakirodalmából kiolvashatók voltak. Eszerint a következőket különböztetem meg: az emberi élet állami, úgymint társadalmi élet folytatása, amely minden mozzanatának állandó őrködéssel történő, szakadatlan szemmel tartása; az alanyi belátás, a széles körű diszkrecionális hatalom és a fizikai erő azonnali alkalmazásának lehetősége. Ezek közül az állandó őrködést és a széles körű diszkrecionális hatalmat Concha a rendőri működés elemeiként vagy legsajátosabb eszközeiként említi. A fizikai erőnek azonnali alkalmazását az előző két elem mellett, a rendőri működésben rejlő különleges erőként tartotta számon. ${ }^{48}$

\section{Az emberi élet, állami és társadalmi élet állandó órködéssel történö szakadatlan szemmel tartása}

Az általános értelemben vett rend mellett Concha az állam, a társadalom és a természet rendjét emeli ki. Az állam és a társadalom rendjének fennállását, a jog

\footnotetext{
47 Alasdair MacIntyre: Az erény nyomában. Budapest, Osiris, 1999, 251-256.

48 Vö. Concha (1901): i. m.
} 
szabályainak érvényesülésétől és az államérdek megvalósulásától teszi függővé. A rendőrség feladatai ebben az alaptényezők mellett az állam és a társadalom rendje előfeltételeinek biztosítása, a társadalmi rend érvényesülését lehetővé tenni és nem magát a rendet. De mit is értett Concha állandó őrködő funkció alatt?

A társadalom tagjainak jog által engedélyezett szabad tevékenységét és javait állandó őrködésével védelmezi a valószínűsíthetően és a ténylegesen bekövetkező támadás ellen; az így felmerülő támadásokat tényleg megakadályozza és a támadásokkal megzavart rendet helyreállítja. ${ }^{49} \mathrm{~A}$ rend tehát a lelke mindennek.

A rend állandó őrködése olyan készségek kialakulását feltételezheti, amelyekkel a természet, a társadalom és az állam múködésében bekövetkező változásokra azonnal reagálni képessé teszi a rendőrt. Az egyik cselekvés hatással van a másikra, amelyek egymásra kölcsönösen hatnak. Az így kialakult hálózatban ok-okozati öszszefüggések egész rendszere áll tehát fel. Az állandó őrködéssel a rendőr szenzitíven képes észrevenni és reagálni a környezetében, a társadalomban beállt legapróbb változásokra. „A jogban, az okozatosságot kezelni kívánó minden stratégiának alapvető jellegzetessége, hogy miképpen különíti el az eredménnyel összefüggő egyszerű körülményeket, tényezőket az eredményt okozó körülményektől, tehát az okoktól."50 A rendőr a szolgálata során ezen összefüggési rendszeren belül mozog, és az állandó őrködő funkciójának köszönhetően képes reagálni a rendekben ${ }^{51}$ bekövetkező változásokra, alanyi belátásához mérten, amiről az alábbiakban írok.

\section{Az alanyi belátás, a széles körú diszkrecionális hatalom}

A rendészeti hivatás gyakorlása épp ennek okán igencsak releváns, hiszen a munkavégzés minden mozzanata morális tartalommal töltődik. Tekintettel a munkavégzés sokrétű voltára, nem válik annak minden részlete szabályozhatóvá, ezért kapnak igencsak nagy szerepet a hivatásos emberek önálló döntései. Concha szerint a diszkrecionális akaratot a tények bizonytalansága és a bekövetkező hatások kiszámíthatatlansága teszik különösen szükségessé.

A rendőri hivatás teljes embert igényel, aminek azért van jelentősége, mert munkája közvetlen kihatással van az állampolgárok életére. A döntését közvetlen közelről, helyesen és rövid idő alatt kell meghoznia. ${ }^{52}$

Erdős István szerint a rendőri szakma fokozott erkölcsi veszélyeztetettsége a következőképpen foglalható össze:

\footnotetext{
Concha (1901): i. m. 307-308.

Blutman László: Okozatosság, oksági mércék és a magyar bírói gyakorlat. Jogtudományi Közlöny, 66. (2011), 6. 310. Például értsd alatta az állami, társadalmi és a természet rendjét.

Nándori Nikoletta Petra: A rendőrség tízparancsolatának bemutatása. Pécsi Határôr Tudományos Közlemények, 20. (2018), 307.
} 


\begin{abstract}
„A jogi normák alkalmazása diszkrecionális feladatokat hárít a rendőrre. A jog általános normáin túlmenően a rendőrnek többnyire egyedül kell döntéseket hoznia. A rendőr a legális erőszak monopóliumával rendelkezik, a hatalommal visszaélés állandó veszélye fenyegeti. A rendőr a bűn közvetlen közelében él és dolgozik, ezért fokozottan veszélyeztetett. A rendőr katonailag, hierarchikusan szervezett testület tagja, az ilyen testületek pedig hajlamosak arra, hogy belső „saját erkölcsöt” alakítsanak ki és várjanak el tagjaitól.”53
\end{abstract}

A rendôr feladatát mindenekelőtt az érvényben lévő és hivatásával összefüggésbe hozható jogszabályi keretek között köteles végrehajtani. Ezen belül speciálisan a hivatásos szolgálati viszonyról szóló törvény, a rendőrségi törvény, a szolgálati szabályzat, továbbá a vezetői utasítások határozzák meg. ${ }^{54} \mathrm{~A}$ jogszabályi hierarchia szabályait szem előtt tartva, vagyis alacsonyabb rendủ jogszabály nem ütheti a felette állót. A méltányosságnak nincsen jogilag egyértelmúen kijelölt határa, amelynek értelmében mérlegeli a rendőr szándékát, a lehetséges következményeket, a követett elvek értékét és végül dönt.

A diszkrecionális döntés Delattre szerint a rendőri hivatás speciális velejárója, amellyel a rend fenntartása és a béke megőrzése érdekében szabad döntések meghozatalára hatalmazzák fel a rendőrt. A különleges szabadságjogok azonban különleges kötelességekkel járnak. Azonban ezekre a diszkrecionális döntésekre sem törvényi sem egyéb szabályozási előírás nincs. ${ }^{55}$ Elengedhetetlen a rendőrök képzése arra vonatkozólag, hogy miként is gyakorolják a számukra biztosított széles körú diszkrecionális/mérlegelési jogkört. ${ }^{56}$

A szabad mérlegelés maga után vonja a szükségesség és arányosság mindenkori figyelembevétele mellett annak kivitelezéséhez kellő fizikai erő meglétét is, amiről a következőkben lehet röviden olvasni.

\title{
A fizikai erô azonnali alkalmazásának lehetösége
}

A diszkrecionális jogkörrel nagymértékben összefügg. A rend megzavarása esetén - az adott helyzet mérlegelésével - fog eldőlni, hogy annak megakadályozására vagy a megzavart rend helyreállítására okán lesz szükség az adott rendőri intézkedésre. A fizikai erő azonnali kifejtésének a kényszeritő eszköz alkalmazása esetén van relevanciája. A szükségesség és arányosság mértékének szem előtt tartásával, továbbá a kényszerítő eszközök használatának feltételeit előíró jogszabályi előírások mellett, a rendőr szabad és egyéni mérlegelésének szintén jelentősége van.

A kényszerítő eszközök használatának mérlegelésére, vagyis a döntésre sok esetben nagyon kevés idő áll a rendőr rendelkezésére. Ezért is elengedhetetlen a kor

\footnotetext{
Erdős István: Szakmai erkölcs: érvek a rendőri etika mellett. Börtönügyi Szemle, 16. (1997), 2. 24-25.

Erdős (1997): i. m. 25.

Edwin J. Delattre: Character and cops. Ethics in policing. Washington D.C., AEI Press, 2011. 49.

6 Delattre (2011): i. m. 50.
} 
kívánalmainak megfelelő felszerelés biztosítása és a hozzá tartozó képzés hatékonysága. A megfelelő felszerelés azt is jelenti, hogy a rendőr számára a szolgálata során rendelkezésére álló kényszerítő eszközök alkalmasak legyenek a szükségeség és arányosság betartására, méghozzá abban a tekintetben is, hogy annak használata során ne okozzon esetlegesen vétlenül nagyobb kárt, mint hasznot.

Mindezen túlmenően a rendôri hivatással együtt járó napi szolgálati feladatok ellátásához általános fizikai erőnlétre is szüksége van. A rendőr működésével együtt járó feladatok ellátásához - így maradva Concha Győző által meghatározottaknál -, úgymint a védelmezéshez, megakadályozáshoz és a helyreállításhoz is nélkülözhetetlen szerepe van a megfelelő fizikai erőnlétnek. Ép testben ép lélek - tartja a mondás. A szolgálati feladatok ugyanis a lélek számára éppen annyira megterhelők lehetnek, mint a test számára. A lélekjelenlét megléte és megőrzése az embert próbáló helyzetekben, mint amilyen jellegéből adódóan a szolgálati feladatok ellátása is, összefüggésbe hozható a bátorsággal mint erénnyel, amiről a következőkben írok.

A bátorság Boda Mihály szerint a legáltalánosabb értelemben véve kezdeményezóképesség, ami szükséges ahhoz, hogy valaki elkezdjen és végrehajtson egy cselekvést. Az általános értelemben vett bátorság nem csupán egy önmagában értelmezhető igencsak fontos erény, hanem nélkülözhetetlen minden más erény múködéséhez is. ${ }^{57} \mathrm{~A}$ felosztása szerint megkülönböztet természetes, mesterséges, hazaszereteten alapuló és erkölcsi-morális bátorságot. A természetes bátorság során az ember erkölcsi szempontból mérlegeli a veszélyhelyzetet és vállalja a veszélyes helyzettel együtt járó következményeket, ami egyszerre ösztönös és tudatos válasz. A mesterséges bátorság már egy tanulási folyamaton alapszik. A természetes bátorság során egyéni tapasztalatoknak van szerepe, a mesterséges bátorság esetében a potenciálisan előforduló veszélyes helyzetek megismerésére, az abban elsajátítható helyes viselkedés begyakorlása által válhat készségszintűvé. A bátorságtípusok harmadik eleme a hazaszereteten alapuló bátorság. Eszerint a haza felé mutatott pozitív érzelem, amely jellegéből adódóan motivációs erőt is magában hordoz. Végül az erkölcsi alapon vagy morálisan bátor ember egy erkölcsi vagy morális cél megvalósítása érdekében cselekvéssel kitartóan uralja a veszélyes helyzetet, amelynek két összetevője van: akaraterő és az az érték, amire az akaraterő irányul. ${ }^{58} \mathrm{~A}$ bátorság tehát valami jónak, helyesnek cselekvéssel történő akaratlagos véghezvitelét jelenti. $\mathrm{Az}$ értelemnek és az akaratnak cselekvésben történő megnyilvánulása.

\section{Összegzés}

A rendőri hivatás társadalomban betöltött szerepe szerinti feladatellátása a jog által szabályozott keretek között tölti be rendeltetését. A hivatás számára meghatározott

\footnotetext{
Boda Mihály: Az alapvető katonai erények mibenléte és helyük a hosszú 19. századi magyar hadtudományos gondolkodásban 2. rész - A bátorság. Hadtudomány, 28. (2018b), 2. 18.

58 Vö. Boda (2018b): i. m. 20-28.
} 
feladatokat így a törvényi felhatalmazás keretein belül jogszerúen, szakszerúen és arányosan köteles végrehajtani. Mindemellett azonban a hivatás gyakorlásának vannak olyan mozzanatai, fázisai és interakciói, amelyekre szolgáló törvényi elóírás nincs, azokat szabályozni nem lehet. Ezért jut ilyenkor igencsak nagy szerep a hivatásos emberek önálló döntéseinek. Az ilyen döntésekkel kapcsolatban az erkölcs szerepe válik meghatározóvá. A jó és a rossz, a helyes és a helytelen közötti választás nem csupán a szolgálati előírások és ellenőrzések által kívülrôl támasztott elvárásoknak történő engedelmességet jelenti, hanem mindinkább válik kiemelt jelentőségúvé a belülrôl jövő tudatos és akaratlagos cselekvés. Az erkölcsi jóra való törekvés, akarati készség, vagyis az erények kialakulása útján válik meghatározó kötelességgé a hivatás gyakorlása során.

A rendôri erények vizsgálata lehetővé teszi a hivatással szemben támasztott elvárások megfogalmazását és feltárását. A dualizmus korában a nemzet belső rendjének megszilárdítása jelentette azt a kiemelt feladatot, amelyet a rendőrségnek kellett biztosítania. Az alaptényezők mellett a rendőrnek az állam és a társadalom rendjének előfeltételeit kellett biztosítani és a társadalmi rendnek az érvényesülését lehetségessé tenni. A társadalmi szerep a hivatásos szolgálatot, vagyis a közjó szolgálatát is jelentette egyúttal. A tanulmány során feltárt erények összefüggést mutatnak egymással, közöttük ok-okozati kapcsolat van jelen. A hivatásszerü munkavégzés és a hivatások léte azonban nem képzelhető el hivatáshoz köthető erények nélkül, ami azt jelenti, hogy a rendészeti tevékenység sem képzelhető el erkölcsi és morális szabályok nélkül. Az ilyen szabályok többek között elősegítik a rendészeti állomány integrációját és ezzel hatékonyabb feladat-végrehajtását, illetve fontos kapcsot képeznek a rendészeti állomány és a társadalom között.

\section{FELHASZNÁLT IRODALOM}

Arisztotelész: Nikomakhoszi Etika. Részletek, I-III. könyv. (Fordította: Szabó Miklós). Budapest, Európa, 1997.

Blutman László: Okozatosság, oksági mércék és a magyar bírói gyakorlat. Jogtudományi Közlöny, 66. (2011), 6. 309-320.

Boda Mihály: Az alapvető katonai erények mibenléte és helyük a hosszú 19. századi magyar hadtudományos gondolkodásban 1. rész - Az erények és a katonai erénylisták. Hadtudomány, 28. (2018a), 1. 38-47. Online: https://doi.org/10.17047/HADTUD.2018.28.1.38

Boda Mihály: Az alapvető katonai erények mibenléte és helyük a hosszú 19. századi magyar hadtudományos gondolkodásban 2. rész - A bátorság. Hadtudomány, 28. (2018b), 2. 18-29. Online: https://doi.org/10.17047/HADTUD.2018.28.2.18

Boda Mihály: Zrínyi hősiességfogalma a katonai hősiesség változó formáinak tükrében. Hadtudományi Szemle, 13. (2020), 2. 79-91. Online: https://doi.org/10.32563/hsz.2020.2.7

Boda Mihály: A filozófiára épülő háborús igazolás (filozófiai militarizmus) a 19-20. században Európában és Magyarországon. Hadtudomány, (2021), (megjelenés alatt)

Concha Győző: A rendőrség természete és állása szabad államban. Értekezések a Társadalmi Tudományok Köréből, 12. (1901), 6. 295-344. 
Concha Győző: Politika I. kötet Alkotmánytan. Budapest, Eggenberger-féle Könyvkereskedés (Hoffmann és Molnár), 1895.

Delattre, Edwin J.: Character and cops. Ethics in policing. Washington D.C., AEI Press, 2011.

Erdős István: Szakmai erkölcs: érvek a rendőri etika mellett. Börtönügyi Szemle, 16. (1997), 2. 20-31. Online: https://epa.oszk.hu/02700/02705/00030/pdf/EPA02705_bortonugyi_szemle_1997_ 2_020-031.pdf

Hegel, Georg Wilhelm Friedrich: A szellem fenomenológiája. Budapest, Akadémiai, 1979.

Hobbes, Thomas: Leviatán. Budapest, Kossuth, 1999.

MacIntyre, Alasdair: Az erény nyomában. Budapest, Osiris, 1999.

Nándori Nikoletta Petra: A rendőrség tízparancsolatának bemutatása. Pécsi Határôr Tudományos Közlemények, 20. (2018), 307-312. Online: www.pecshor.hu/periodika/XX/nandori.pdf

Rousseau, Jean-Jacques: A társadalmi szerződésről. Budapest, PannonKlett, 1997.

Sallai János: Concha Győző, a rendészet jeles tudósa. Magyar Rendészet, 15. (2015), 1. 39-45.

Taylor, Charles: Hegel. Cambridge University Press, 1975. Online: https://doi.org/10.1017/ CBO9781139171465

Warburton, Nigel: Bevezetés a filozófiába. Budapest, Kossuth, 2000.

\section{ABSTRACT}

\section{Gyözö Concha and Police Virtues}

Nikoletta Petra NÁNDORI

Why are virtues important to police officers? Performing the duties of a police profession requires skills that enable the best possible performance of day-to-day service. I examine these in a special way through the works of Gyözö Concha, one of the prominent representatives of the Hungarian public law, but the works of other writers related to the topic also play a role in my essay. In this study, I seek virtues that can play a significant role in the work of the police in the age of dualism. My goal is to find elements that are independent of the state and social system, which have a decisive importance in enabling the law enforcement work of the police officer.

Keywords: police virtues, constant guarding, discretionary power, use of physical force 